shown (I am not aware that it can) that be had definitely correlated them with (Lower) Cambrian beds.

St. John's College, Cambridge, December II

\section{Self-Fertilisation in Flowers}

Dr. Müller (Nature, vol. xiv. p. 57x) and Prof. Asa Gray (vol. xv. p. 24) reflect on your abstract of my verbal remarks (vol. xiv. p. 475) on Browallia in a way not "particularly complimentary to me. Prof. Gray admits having read the full report, and yet fails to notice that "February 8 ", is there given as the date of my remarks. Had he not overlooked this, he would not have wondered that I did not see "Hymenoptera and Lepidoptera of various sorts" visiting them. As reported in the Proceedings of the Society, I exhibited fresh specimens in fruit at the meeting of that date, which is about mid-winter with us, when these insects are at rest. The plants were of course grown under glass, and when I say "Browallia is not visited by insects, yet seeds abundantly," I am referring naturally to the experience I am describing. If one be justified in taking an unguarded expression, or even a whole sentence, without any regard to the subject matter of its connection, we might have as many "theories" in science as there are sects in religion, all founded on isolated "texts" in Scripture. It is remarkable that in a paper in which Prof. Gray is commenting on hasty observations, in another he should have overlooked a fact like this. I do not say Browallia is never visited by insects, but I do say that they do not visit them under such circumstances as $I$ was describing.

Of the fact there is no doubt, of the interpretation there may be many opinions ; and no one respects an opinion by Prof. Gray, when he carefully considers it, more highly than I. Yet I would respectfully submit, that even though an insect were as careful to avoid the "brush" which almost closes the throat, though it were able to be as careful in finding the chink as Dr. Gray was in his manipulations with the hog's bristle, the obstruction of the mouth in the way it is cannot surely be claimed as an arrangement in favour of cross-fertilisation.

Dr. Miiller seems to believe that I do not know that "many flowers have recourse to self-fertilisation when not visited by insects." If he will examine the Proceedings of the Am. Association for 1875, p. 247 , he will find that I have given bim the credit of the observation, and the fact itself such consideration I thought it in justice entitled to. The impression which Dr. Miiller's expression warrants, that he has not had the opportunity of reading the numerous observations $\bar{I}$ have placed on record during the last few years, in relation to this and kindred topics, fully excuses him in my mind for his sharp comments.

Germantown, Philadelphia, Nov, 2 I Thomas MeEhaM

\section{On Supersaturated Solutions}

IN a paper communicated to the Royal Society last May I described some experiments to show that the open air and the air of ordinary rooms do not generally contain crystals of the various salts which form supersaturated solutions. It has been remarked to me that $I$ did not give the strength of the solutions, so that doubt might arise as to whether the results would hold good for very strong solutions:-The following experiments set that question at rest. I made a very strong solution of sodium sulphate which threw down abundance of anhydrous salt on boiling. When cold a good half inch of anhydrous salt remained at the bottom of the test-tube. Took this into my garden, which is near Bristol. Took up some of the solution in a clean pipette and put drops on the leaves of peonies, which were very dusty, on geraniums, on moss, on the stone coping of Bath oolite, and on the painted woodwork of the railings and garden door. Not a single drop crystallised. Made a drop set quite solid by dropping in earth with the fingers. N.B.- I had been at work with the salt for some time and crystals were probably adhering to my finger. Earth not touched inactive. The drops sank into the moss slowly, remaining quite liquid. Those on the stone were soon absorbed and dried up on the surface; fresh drops put on these remained liquid. Smeared a drop repeatedly with the finger which had been cleansed; inactive, as fresh drops remained liquid on it. Drop on flower-pot, inactive, smeared with finger; when dry inactive to fresh drops. These and other drops on the flower-pot slowly formed a film of 7-atom salt. Stirred the solution with a dry twig picked off the ground, inactive. The drops on the leaves all slowly evaporated, giving the 7 -atom salt. Finally, made some of the drops and the original solution crystallise, to prove that they were really supersaturated. These experiments were made both in sun and shade. Weather dry. The test-tube was left open the whole time.

On another occasion I took a flask of sodium sulphate containing a large quantity of the 7-atom salt into the garden in the evening. Put drops on a flower-pot; one only crystallised. Put a lump of dry earth into one drop, and added more solution; did not crystallise. Made a little mud pie by breaking this up with the pipette, inactive; pipette repeatedly inactive in the solution after touching this. Brought a crystal to the earth; crystallised at once all through the mass.

Clifon College

\section{J. G. GRENFELL}

\section{KARL ERNST VON BAER}

SCIENCE has sustained a great loss by the death of Dr. Karl Ernst von Baer, the eminent biologist; he died at Dorpat on November 29, in his eighty-fifth year. Von Baer was born in Esthonia on February 29, 1792, and while yet at the gymnasium became an earnest student of botany. He studied medicine at Dorpat in I810-I4, whence he proceeded to Vienna for the study of clinical medicine, to Würzburg, where he gave special attention to comparative anatomy, and to Berlin, where he studied magnetism, electricity, crystallography, and geology. In 1817 he went to Königsberg as prosector to Prof. Burdach, and two years later he became professor of zoology at the same university. In 1826 he succeeded Burdach in the chair of anatomy, accepted an invitation in 1829 from the St. Petersburg Academy, but returned to Königsberg the following year. A few years later, in 1834 he was again invited to St. Petersburg, where he became one of the most active members not only of the Academy, but also of the Geographical and Economical Societies. Von Baer's writings, marked by philosophic depth, are, on account of their orderly and clear exposition, as attractive as they are generally intelligible. The subject of the origin and development of organic bodies, which had special attractions for him, he did much to clear up. The foundation of his eminence he laid in Königsberg, where he published in 1827 his "Briefe über die Enstehung des Eies," which was soon followed by the important works "Entwickelungsgeschichte der Thiere," and "Geschichte der Entwickelung der Fische." These works, which are yet of great value, have earned for their author the title of Father of Comparative Embryology.

In the summer of 1837 von Baer made a journey of exploration from Archangel to Novaya Zemlya, and his report is still one of the most valuable sources of information upon that island. In $185 \mathrm{I}$ his attention was attracted to the immense Russian fisheries and the irrational methods used. During 185 I. 6 he investigated the fisheries of Lake Peipus, the Gulf of Finland, and the Caspian Sea, publishing the results of his investigations in a great work in 1859 . The name of Baer is connected with more than one improvement in the fisheries, and some important additions were made to the trade, thanks to his efforts. His remarkable work, "Kaspische Studien," has had no rival. It would be impossible to enumerate the various subjects upon which he has thrown clear light in his writings. The laws of excavation of river-beds, the navigability of the Arctic seas, the steppes and forests of Southern Russia, the Glacial period, the Siberian mammoths, the potato disease, were at various times treated by him, and in each department von Baer opened out new and extensive fields of inquiry. His acquirements in zoology, comparative anatomy, embryology, physiology, and anthropology are well known; moreover ethnography, the early history of mankind, archæology, and the science of language will count him among their most eminent students. In his later years, besides various anthropological papers, he published an autobiography (which appeared soon after the fiftieth anniversary-1864-of his scientific career), his "Reden," and "Kleine Aufsätze vermischten Inhalts" 